\title{
Economic Policy Uncertainty and Enterprise Financialization under the Condition of Informationization
}

\author{
Miao $\mathrm{He}^{\mathrm{a}^{*}}$ \\ Lanzhou University of Technology, School of Economics and Management, Lan Zhou, Gan Su, China
}

\begin{abstract}
ABSRTACT: Information is the current global development trend, is an important force driving economic change. The incompleteness of information leads to the fluctuation of economy, which urges the government to carry on the macro-policy regulation and control, thus affects the micro-enterprise decision-making. Based on the perspective of financialization, this paper empirically tests the relationship between economic policy uncertainty and enterprise financialization under informatization, and finds that there is a significant positive correlation between them. This paper enriches the relevant literature on the uncertainty of economic policy and the financialization of enterprises under the information age, and has some practical significance for enterprises to make rational decisions when they face the uncertainty of economic policy under the information age.
\end{abstract}

\section{Introduction}

The National Informatization Development Strategy 2006-2020, published by the State Council General Office in 2006, holds that informatization is to make full use of information technology to develop information resources, promote information exchange and improve the quality of economic development. Information leads to information explosion and information gap. The limitations of the level of economic development and self-cognitive ability result in incomplete information, which makes the market can not make full use of information to allocate resources, and then produce economic fluctuation ${ }^{1}$. Moreover, financial crises throughout history have shown that markets can not do it all. If relying only on the self-recovery ability of the market can not stabilize the market, efficient allocation of market resources, then the need for government intervention. The government is the maker of economic policy, and the micro-subject is the recipient of economic policy. On the one hand, for policy recipients, the uncertainty of economic policy indicates that the various regulatory policies formulated by the government are covert, and micro-enterprises can not predict in advance the content of the policies issued by the government, the enterprise can not make the response in advance to adjust the management decision. On the other hand, the government can not make accurate and timely forecast for the policy makers, facing the ever-changing economic environment under the information background. Therefore, the regulation policy issued by the government may also lag behind the market situation, leading to the government itself to make and release the existence of uncertainty. Based on the analysis of the above two aspects, the uncertainty of economic policy

* Corresponding author: ${ }^{\text {a } 1355238998 @ q q . c o m}$ leads to the fluctuation of the economy, and then affects the business decision-making.

Investment is very important in the decision-making of enterprises. Under the background of informationization, the real industry is affected by the change of market demand, and the rate of return on investment is constantly falling, which causes non-financial enterprises to flood into the financial industry and the real estate industry, the more prevalent investment in financial assets led to the financialization of the economy. The phenomenon of the economic financialization is reflected in the enterprise, so the enterprise financialization is the microcosmic embodiment of the economic financialization. The real sector faces overcapacity, plummeting yields and, by contrast, fast-growing returns on investment in the financial sector, which has led non-financial companies to invest in financial assets. Milberg argues that the decline in physical investment has led to high returns on financial investments ${ }^{2}$. Overconfident management with financial background and overseas background can influence the financialization of enterprises ${ }^{3}$. Most of the existing literature studies the financialization of enterprises from the perspective of economic financialization and the characteristics of its managers, but seldom studies the management and investment decisions of micro-enterprises based on the uncertainty of economic policies in the context of informatization, in particular, corporate financialization. Therefore, this paper studies the impact of economic policy uncertainty on business decision-making from the perspective of corporate financialization, it is of practical significance for enterprises to make rational decision when facing the uncertainty of economic policy under the information globalization. 


\section{Research Hypothesis}

According to the existing literature, firms make conservative decisions to reduce losses when facing economic uncertainty. Based on the theory of financial friction, uncertain events can increase the Information asymmetry of capital market, increase investment cost and financing constraints, and reduce investment returns. Therefore, when the economic policy is uncertain, the enterprises will tend to reduce the financial investment because of the uncertain income and the difficulty of financing. Therefore, hypothesis 1 is proposed: the uncertainty of economic policy will restrain the financialization of enterprises.

According to the existing literature, the liquidity of financial assets is strong, when the business crisis occurs due to the uncertainty of time, it can substitute cash to alleviate the situation of enterprises. On the one hand, according to the reservoir theory, enterprises will make precautionary savings in order to deal with possible economic policy uncertainty. Compared with cash, investment in financial assets has a high return; compared with fixed assets, financial assets are more liquid and easy to be realized. On the other hand, according to the real option theory, the uncertainty of economic policy contains double information, which may be beneficial to the development of enterprises. If the enterprise managers have a long-term vision and risk-taking spirit, they will tend to increase business investment, increase the competitiveness of enterprises. But the financial assets investment has the characteristic of high return rate at present, therefore the enterprise will be inclined to carry on the financial assets investment when making the investment, increases the enterprise income. Therefore, based on the above two aspects of the analysis, enterprises will increase investment in financial assets. Hypothesis 2: economic policy uncertainty promotes corporate financialization.

\section{Research Design}

\subsection{Sample Selection and Data Sources}

This paper selects Shanghai and Shenzhen a-share listed companies as the initial sample from 2010 to 2019, and excludes the following samples: (1) ST, ST * companies; (2) financial and insurance listed companies; (3) missing data. In order to eliminate the influence of the extreme value, the tail-shrinking process was carried out at the level of $1 \%$ above and below the continuous variable. After processing, 10189 observations were obtained. Economic policy uncertainty data from Steven J. Davis et al. based their measurement of economic policy uncertainty on Baker et al.'s China Economic Policy Uncertainty Index, compiled by a mainland newspaper. Other financial data come from CSMAR database and RESET database, and use Excel and STATA13.0 to deal with the data and empirical analysis.

\subsection{Variables and Model}

(1) Dependent variable-- corporate financialization.

As for the measurement of enterprise financialization, according to the literature ${ }^{5}$, the ratio of financial assets to total assets is used to measure. The financial assets in this article do not include monetary funds. Enterprises hold financial assets mainly for capital appreciation, while most of the monetary funds are used in the daily business activities of enterprises. In addition, in view of the rapid development of the real estate industry in recent years, listed companies hold investment real estate for profit, so investment real estate as a type of financial assets. According to the literature, financial assets eventually included in the analysis include transactional financial assets, available-for-sale financial assets, hold-to-maturity investments, loans and advances, derivative financial assets, dividends receivable and interest and investment real estate 3 .

(2) Independent variable--economic policy uncertainty.

Economic policy uncertainty, expressed in the index of economic policy uncertainty EPU. Take the monthly data arithmetic mean and divide by 100 .

(3) Control Variables.

Drawing on existing research ${ }^{6}$, control enterprise scale, property right nature, assets and liabilities rate, growth, profitability, cash flow level, senior management holding level, the proportion of sole directors, two posts in one.

Table 1 Variable Interpretation

\begin{tabular}{cccc}
\hline Dependent variable & Corporate financialization & Fin22 & Financial assets/total assets \\
\hline Independent variable & Economic policy uncertainty & EPU & $\begin{array}{c}\text { From Steven J. Annual average of EPU } \\
\text { index constructed by Davis et al. }\end{array}$ \\
Control variables & Corporate Nature & SIZE & Natural logarithm of total assets \\
& Ratio of assets to liabilities & SOE & $\begin{array}{c}\text { State-owned enterprises are recorded } \\
\text { as 1 and non-state-owned enterprises } \\
\text { as 0 }\end{array}$ \\
Profitability & LEV & Total liabilities/Total Assets \\
Y & Net Profit/total assets
\end{tabular}


Growth

Cash flow level

Senior Management Stake

Two jobs in one

Exclusive share
Growth

Cash

LZ

DD
Growth rate of operating income

NET cash flow from operating activities/total assets at end of period

Number of shares held by senior executives

If the chairman of the board and the general manager are both the same person, then 1 , otherwise 0

Number of sole directors/number of directors
Build the following model based on the research assumptions:

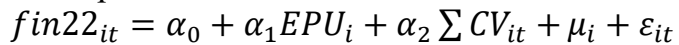

Fin $22_{i t}$ is a measure of the degree of corporate financialization of Company $i$ in year $t, E P U$ is an index of economic policy uncertainty in year t, CVs is a set of control variables. Control the time-fixed effect $\mu_{i}$ and $\varepsilon_{i t}$ represents the disturbance term. The relationship between economic policy uncertainty and enterprise financialization is judged by observing the sign and significance of coefficient. If it is significantly positive, it means that the uncertainty of economic policy promotes the financialization of enterprises, whereas it inhibits the financialization of enterprises.

\section{Empirical Test and Result Analysis}

\subsection{Descriptive Statistics}

Table 2 provides descriptive statistics for the main variables. The maximum value of economic policy uncertainty is 3.634 , and the minimum value is 0.921 , which shows that China's economic policy uncertainty is large. By observing the mean and median of corporate financialization, it shows that there is a big gap between the degree of financialization of domestic listed companies. The descriptive statistics of other variables are within the normal range.
Table 2 Descriptive Statistics for Each Variable

\begin{tabular}{ccccccc}
\hline & $\begin{array}{c}\text { Sample } \\
\text { size }\end{array}$ & Mean & SD & Min & P50 & Max \\
\hline EPU & 10189 & 1.051 & 0.151 & 0.921 & 0.955 & 3.634 \\
Fin22 & 10189 & 0.030 & 0.069 & 0.000 & 0.005 & 0.949 \\
SIZE & 10189 & 22.013 & 1.324 & 19.436 & 21.824 & 26.382 \\
LEV & 10189 & 0.435 & 0.220 & 0.046 & 0.425 & 0.928 \\
Growth & 10189 & 0.162 & 0.519 & -0.588 & 0.069 & 3.705 \\
YL & 10189 & 0.037 & 0.052 & -0.153 & 0.033 & 0.197 \\
Cash & 10189 & 0.041 & 0.072 & -0.193 & 0.040 & 0.240 \\
DD & 10189 & 0.373 & 0.053 & 0.333 & 0.333 & 0.571 \\
\hline
\end{tabular}

\subsection{Correlation Analysis}

The main variables are tested by Pearson correlation coefficient, and the concrete results are shown in table 3. According to the data in the table, economic policy uncertainty and corporate financialization are significantly negative at the level of $1 \%$, which indicates that economic policy uncertainty will affect corporate financialization. In addition, the absolute correlation coefficient of each variable is below 0.7 , which indicates that there is no Multicollinearity between the variables in the model.

Table 3 Analysis of Correlation among Variables

\begin{tabular}{|c|l|l|l|l|l|l|}
\hline & \multicolumn{1}{|c|}{ Fin22 } & \multicolumn{1}{c|}{ EPU } & SIZE & Lev & Growth & Cash \\
\hline Fin22 & 1.000 & & & & & \\
\hline EPU & $-0.048 * * *$ & 1.000 & & & & \\
\hline SIZE & 0.001 & $-0.053 * * *$ & 1.000 & & & \\
\hline LEV & -0.001 & -0.006 & $0.514 * * *$ & 1.000 & & \\
\hline Growth & -0.005 & -0.004 & $0.021 *$ & $0.031 * *$ & 1.000 & \\
\hline Cash & $-0.060 * * *$ & -0.004 & $0.054 * * *$ & $-0.155 * * *$ & -0.009 & 1.000 \\
\hline
\end{tabular}




\subsection{Regression Analysis}

The results of the specific regression analysis will be shown in table 4. Column (1) does not include control variables, and the regression results show that economic policy uncertainty and corporate financialization are significantly negative at the $1 \%$ level. The direction and significance of column (2) with control variables are the same as that without control variables, but the coefficient decreases, which shows that control variables also have some influence on enterprise financialization. The results show that the greater the uncertainty of economic policy, the less the financial investment of listed companies, that is to say, the uncertainty of economic policy restrains the degree of enterprise financialization.

Table 4 Regression Results

\begin{tabular}{|c|c|c|}
\hline & Fin 22 & Fin 22 \\
\hline \multirow[t]{2}{*}{ EPU } & $0.009 *$ & $0.014 *$ \\
\hline & $(1.805)$ & $(2.556)$ \\
\hline Year & Yes & Yes \\
\hline $\mathrm{CVs}$ & No & Yes \\
\hline id & Yes & Yes \\
\hline \multirow[t]{2}{*}{ _cons } & $0.019 * *$ & $0.245 * * *$ \\
\hline & (2.918) & (3.767) \\
\hline $\mathrm{N}$ & 10189 & 10189 \\
\hline $\mathrm{R} 2$ & 0.058 & 0.068 \\
\hline
\end{tabular}

\section{Conclusion}

Informationalization promotes the occurrence of uncertainty. The incompleteness of information leads to the fluctuation of economy, which urges the government to carry on the macro-policy regulation and control, thus affects the micro-enterprise decision-making. Based on the perspective of financialization, this paper empirically tests the relationship between economic policy uncertainty and enterprise financialization under informatization, and finds that there is a significant positive correlation between them. This paper enriches the relevant literature on the uncertainty of economic policy and the financialization of enterprises under the information age, and has some practical significance for enterprises to make rational decisions when they face the uncertainty of economic policy under the information age. As the lifeblood of national economy, the development of financial industry should serve the real economy. The Supervision Department should strengthen the financial supervision with the information technology, solve the problem of enterprise financing restriction, and increase the vitality of the real economy.

\section{References}

1. Lu Z., Zheng C.Y..(2013) Economic fluctuation mechanism and macroeconomic policy under the condition of informationization. Engineering research-engineering from an interdisciplinary perspective, 5(02) : 160-165.

2. Milberg W:.(2008) Shifting Sources and Uses of Profits: Sustaining US financial organization with Global Value Chains. Economy \& Society, 37(3) : 420-452.

3. Du Y., Xie J., Chen J.Y..(2019) CEO financial background and corporate financialization. China's industrial economy, 374(5) : 136-154.

4. Gong G.M., Xiao B.Y..(2020) Overseas background director and entity enterprise financialization. Industrial Technology economy, 39(9) : 121-129.

5. Du Y., Zhang H., Chen J.Y..(2017) The impact of financialization on the future development of the main business of the entity enterprise: Promotion or inhibition. China's industrial economy, 357(12) : 113-131.

6. Song J., Lu Y..(2015) U-shaped relationship between non-monetary financial assets and operating returns: evidence from financialization of listed non-financial companies in China. Financial Research, 420(6) : 111-127.

7. Du Y., Xie J., Chen J..(2019) CEO financial background and corporate financialization. China's industrial economy, 374(5): 136-154 